\title{
PEMBELAJARAN GEOMETRI BERBANTUAN APLIKASI MOBILE AUGMENTED REALITY PADA SISWA EKSTROVERT DAN INTROVERT
}

\author{
Kartini $^{\text {1) }}$, Sudirman ${ }^{2)}$, Wiwit Damayanti Lestari ${ }^{3)}$ \\ ${ }^{1), 2), 3)}$ Program Studi Pendidikan Matematika, Universitas Wiralodra, Jln. Ir. H. Djuanda Km3 \\ Singaraja Indramayu, Jawa Barat, Indonesia \\ tkartini410@gmail.com ${ }^{1)}$,sudirman@unwir.ac.id ${ }^{2)}$,wiwitdamayantilestari@unwir.ac.id ${ }^{3)}$
}

\begin{abstract}
The purpose of this study were to determine the geometry learning process using the Augmented Reality mobile application for extrovert and introvert students, to know the mastery of cube and beam material in extrovert and introvert students. This research is a qualitative study with the participants of class VIII in one of the junior secondary private schools in Indramayu 2019/2020 academic year, from the study participants 4 students were taken as respondents or interview research participants. The selection of respondents is based on personality types that are determined through personality questionnaires and information from mathematics teachers who already know the student's personality, where two participants represent extrovert and introvert personality types. Based on the result of data analysis, we concluded as follow: In the learning process, extrovert students are more active than introvert students. Extrovert students prefer to study in groups so that the discussion results obtained are higher. However, the results of the tests carried out individually were actually the introvert students who were superior, this was because introverted students were more careful in solving the test questions.
\end{abstract}

Keywords: Geometry Learning, Augmented Reality Mobile Application, Extrovert and Introvert Personality Types

Abstrak
Tujuan penelitian ini untuk mengetahui proses pembelajaran geometri menggunakan aplikasi mobile
Augmented Reality pada siswa ekstrovert dan introvert, untuk mengetahui penguasaan materi kubus
dan balok pada siswa ekstrovert dan introvert. Penelitian ini adalah penelitian kualitatif dengan
partisipan siswa kelas VIII di salah satu sekolah swasta menengah pertama yang ada di Indramayu
tahun pelajaran 2019/2020, dari partisipan penelitian tersebut diambil 4 siswa sebagai responden atau
partisipan penelitian wawancara. Pemilihan responden tersebut dilakukan berdasarkan tipe
kepribadian yang ditentukan melalui angket kepribadian dan informasi dari guru matematika yang
sudah mengetahui lebih dulu kepribadian siswanya, dimana dua partisipan mewakili tipe kepribadian
ekstrovert dan introvert. Berdasarkan analisis data, diperoleh kesimpulan sebagai berikut: Dalam
proses pembelajaran siswa ekstrovert lebih aktif dari siswa introvert. Siswa ekstrovert lebih
menyukai belajar secara berkelompok sehingga hasil diskusi yang diperolehpun lebih tinggi. Namun,
hasil yang tes yang dilakukan secara individu justru siswa introvert yang lebih unggul hal ini karena
siswa introvert lebih teliti dalam menyelesaikan soal tes.
Kata Kunci : Pembelajaran Geometri, Aplikasi Mobile Augmented Reality (AR), Tipe Kepribadian
Ekstrovert dan Introvert

Cara Menulis Sitasi: Kartini, Sudirman, \& Lestari, W., L. (2020). Pembelajaran Geometri Berbantuan Aplikasi Mobile Augmented Reality pada Siswa Ekstrovert dan Introvert. Jurnal Edukasi dan Sains Matematika (JES-MAT),6 (2), 139-156. 


\section{PENDAHULUAN}

Perkembangan teknologi dalam bidang pendidikan khususnya dalam proses pembelajaran, menuntut guru untuk selalu meningkatkan kemampuan dalam bidang teknologi pembelajaran. Hamiti \& Reka (2012) menjelaskan bahwa banyak manfaat dari penggunaan teknologi dalam pembelajaran, diantaranya : (1) teknologi memungkinkan guru untuk melakukan halhal yang tidak mungkin dilakukan di lingkungan kelas tradisional; (2) penggunaan teknologi guru dapat mengubah metode pembelajaran; (3) teknologi dapat membantu guru untuk menggunakan pengajaran waktu lebih efektif dan mengendalikan beban kerja mereka; (4) guru dapat meningkatkan sumber daya; (5) berdampak positif pada peningkatan kualitas pengajaran dan pembelajaran; (6) memberikan lebih banyak fleksibilitas baik untuk siswa dan guru. Namun, jika kita lihat berdasarkan data dari Kepala Pusat Teknologi Informasi dan Komunikasi Pendidikan dan Kebudayaan (Kapustekkom) Kementerian Pendidikan dan Kebudayaan, Gogot Suharwoto mengatakan hanya 40 persen guru non teknologi informasi dan komunikasi (TIK) yang siap dengan teknologi (Republika.co.id, 2018).

Banyak teknologi yang digunakan dalam proses pembelajaran khususnya pembelajaran matematika seperti : (1) penggunaan aplikasi geogebra yang dapat membantu siswa dalam mencari koordinat pada pembelajaran geometri (Abdul dkk., 2010); (2) Multimedia Flash digunakan untuk mempelajari matematika dasar (Manurung dkk, 2018); (3) penggunaan aplikasi Augmented Reality (AR) dalam pembelajaran matematika khususnya geometri dapat digunakan siswa sebagai media pembelajaran geometri dalam bentuk 3D (Banu, 2012; Bergig dkk., 2009; Sudirman dkk, 2020).

Salah satu teknologi yang digunakan dalam membantu proses pembelajaran matematika yakni Augmented Reality (AR). Menurut Bajura \& Neumann (1995) augmented reality membantu pengguna untuk berinteraksi dengan objek nyata yang dihasilkan komputer dengan menampilkan objek virtual 3D yang terdapat di lingkungan asli pengguna. Teknologi AR merupakan salah teknologi yang sedang marak digunakan dalam bidang pendidikan. Hung, Chen \& Huang (2017) menjelaskan bahwa penggunaan AR dalam bidang pendidikan dapat membantu siswa untuk melakukan fungsi kognitif yang berbedabeda dan mengordinasikan sumber daya sesuai tindakan, sehingga dapat meningkatkan pembelajaran. Beberapa peneliti telah menggunakan teknologi AR ke dalam pembelajaran matematika seperti yang telah dilakukan oleh Liao, Yu \& Wu (2015) mengembangkan sistem AR untuk membantu siswa dalam memecahkan Rubik kubus dan mempelajari konsep-konsep geometri volume dan geometri ruang. Selain itu penggunaan aplikasi AR pada geometri dimensi 3 dapat meningkatan respon yang positif pada siswa (Astriawati, dkk, 2020). Serta dapat meningkatkan interaksi kegiatan pembelajaran (Sudirman dkk., 2020). Penggunaan teknologi berbasis AR telah banyak digunakan pada penelitian-penelitian sebelumnya. Namun, belum ada yang melakukan penelitian penggunaan teknologi berbasis AR melihatnya dari aspek kepribadian siswa, 
maka penulis tertarik untuk mengadakan penelitian mengenai "Pembelajaran Geometri Berbantuan Aplikasi Mobile Augmented Reality (AR) pada Siswa Ekstrovert dan Introvert."

\section{LANDASAN/KAJIAN TEORI Pembelajaran Geometri}

Pembelajaran merupakan suatu upaya yang dilakukan guru untuk membantu siswa belajar dalam memahami suatu materi tertentu. Nitko \& Brookhart mendefinisikan pembelajaran sebagai proses menyediakan kondisi untuk membantu siswa mencapai tujuan belajar (Ariani \& Widjajanti, 2016). Pembelajaran yang baik adalah yang dapat melibatkan peserta didik untuk aktif dalam proses pembelajaran (Nuriyatin \& Hartono, 2016). Proses pembelajaran merupakan interaksi edukatif antara peserta didik dengan lingkungan sekolah. Dalam hal ini sekolah dapat memilih strategi, metode, dan teknikteknik pembelajaran yang paling efektif sesuai dengan karakteristik mata pelajaran, karakteristik siswa, karakteristik guru, dan kondisi sumber daya yang ada di sekolah. Sehingga dapat memberikan pembelajaran yang bermakna (meaningfull learning) bagi peserta didik (Rahmawati, 2011).

Geometri merupakan salah satu pelajaran matematika yang memuat konsep mengenai titik, garis, bidang dan bendabenda ruang beserta sifat-sifatnya, ukuranukurannya, antara satu dengan yang lain (Zainul \& Prima, 2018). Geometri memiliki kaitan yang erat dengan materi matematika lainnya, seperti konsep pecahan dikoneksikan dalam geometri serta rasio dan perbandingan terkait langsung dengan konsep kesebangunan dalam geometri Budiarto \& Artiono (2019). Oleh karena itu geometri memiliki peranan penting untuk dipelajari. Menurut Walle (Suwito, 2017) pentingnya mempelajari geometri, yaitu: 1) geometri sangat berhubungan erat dengan kehidupan sehari-hari; 2) geometri dapat meningkatkan kemampuan pemecahan masalah; 3) geometri memiliki peran penting dalam mempelajari cabang matematika lainnya; 4) dan mempelajari geometri sangat menyenangkan.

Berdasarkan uraian di atas dapat disimpulkan bahwa pembelajaran geometri merupakan suatu usaha guru dalam menyampaikan materi yang berkaitan dengan titik, garis, bidang dan benda-benda ruang beserta sifat-sifatnya, ukuranukurannya, antara satu dengan yang lain untuk mencapai tujuan belajar.

\section{Aplikasi Mobile Augmented Reality}

Ronald T. Azuma (Chiang dkk., 2014) menjelaskan bahwa Augmented Reality (AR) merupakan salah satu bagian dari Virtual Environments (VE) atau yang biasa disebut dengan Virtual Reality (VR). AR memiliki tiga karakteristik yaitu menggabungkan dunia maya dua dimensi ataupun tiga dimensi ke dalam sebuah lingkungan nyata, adanya interaksi secara langsung dunia maya dengan lingkungan nyata, dan dapat menampilkan objek 3D. Berdasarkan karakterisitik tersebut, Sudirman dkk., (2020) mengungkapkan bahwa penggunaan AR dalam pembelajaran mampu (1) menumbuhkan kemampuan kinestetik; (2) meningkatkan pemahaman materi pembelajaran; meningkatkan motivasi dan keterlibatan siswa dalam pembelajaran; memperkenalkan hubungan kontekstual.

Aplikasi AR yang digunakan peneliti dalam pembelajaran diadopsi pada penelitian Sudirman, dkk (2020) yakni Etnicar TG 4.0. Etnicar TG 4.0 yaitu suatu aplikasi yang mengintegrasikan 
etnomathematik ke dalam AR pada konten materi geometri. Adapun langkah-langkah pembelajaran menggunakan AR yaitu: (1) siapkan handphone dan marker sesuai yang dibutuhkan; (2) buka aplikasi mobile AR; (3) pilih menu ayo bermain AR pada aplikasi tersebut; (4) arahkan kamera handphone pada marker; (5) muncul gambar berbentuk 3D pada handphone.

\section{Tipe Kepribadian Ekstrovert dan Introvert}

Kepribadian

seseorang

mempengaruhi dalam menentukan suatu pilihan. Tuhan menciptakan manusia selain dengan ciri-ciri fisik yang berbeda juga memiliki karakter dan sifat yang berbeda pula (Fatmawati \& Khabibah, 2019). Jung (1921) mengelompokkan tipe kepribadian menjadi dua yaitu tipe kepribadian ekstrovert dan tipe kepribadian introvert.

Rosida \& Astuti (2015)

mengungkapkan bahwa kepribadian ekstrovert adalah kesiapan individu untuk berperilaku menyukai situasi yang melibatkan banyak orang, berani mengambil resiko, suka bertindak tanpa banyak berpikir, cenderung lebih memperlihatkan keadaan emosinya secara terbuka, lebih suka langsung bertindak daripada berangan-angan, dan cenderung tidak konsisten. Rahayu \& Fauziah (2017) menjelaskan bahwa kepribadian introvert adalah individu yang mempunyai ciri-ciri suka belajar sendiri, berhati-hati dalam mengambil keputusan, tenang dan rajin dalam melakukan pekerjaan. Maka orang introvert akan lebih tekun jika melakukan pekerjaan dengan sendiri.

\section{METODE PENELITIAN Jenis Penelitian}

Jenis penelitian ini adalah penelitian kualitatif deskriptif, karena penelitian ini mendeskripsikan atau menggambarkan penguaasaan materi kubus dan balok dalam pembelajaran geometri berbantuan aplikasi mobile Augmented Reality pada siswa ekstrovert dan introvert.

\section{Waktu dan Tempat Penelitian}

Penelitian ini dilaksanakan di salah satu sekolah swasta menengah pertama yang ada di Indramayu beralamatkan $\mathrm{Jl}$. Manunggal RT.09/RW.03, Dermayu, Kecamatan Sindang, Kabupaten Indramayu, Jawa Barat 45223. Kegiatan penelitian ini dilaksanakan dari tanggal 13 Januari 2020 sampai dengan 31 Januari 2020.

\section{Subjek/Partisipan}

Partisipan dalam penelitian ini adalah siswa kelas VIII di salah satu sekolah swasta menengah pertama yang ada di Indramayu, dari partisipan penelitian tersebut diambil 4 siswa sebagai responden atau partisipan penelitian wawancara. Pemilihan responden tersebut dilakukan berdasarkan tipe kepribadian yang ditentukan melalui angket kepribadian dan informasi dari guru matematika yang sudah mengetahui lebih dulu kepribadian siswanya, dimana dua partisipan mewakili tipe kepribadian ekstrovert yaitu siswa yang lebih banyak berbicara ketika pembelajaran di kelas dan dua subjek mewakili tipe kepribadian introvert yaitu siswa yang memiliki pribadi pendiam dan pemalu.

\section{Prosedur}

Pada proses awal peneliti melakukan observasi ke salah satu Sekolah Menengah Pertama yang ada di Indramayu. Selanjutnya, peneliti menganalisis kebutuhan yang muncul pada sekolah tersebut. Setelah menganalisis kebutuhan yang nampak, peneliti menegosiasikan penggunaan aplikasi mobile AR untuk 
membantu proses pembelajaran geometri. Bersama dengan guru, peneliti mendiskusikan kelas dan metode yang digunakan untuk diintegrasikan dengan aplikasi AR. Setelah semua ditentukan, selanjutnya peneliti mulai menerapkan aplikasi AR ke dalam pembelajaran siswa kelas VII berdasarkan tipe kepribadian. Guru bersama peneliti mengelompokan siswa menjadi dua kelompok yakni kelompok ekstrovert dan introvert. Selama 4 pertemuan siswa belajar dalam kelas, selanjutnya dilakukan evaluasi untuk mengukur pemahaman konsep siswa pada kelompok ekstrovet dan introvert. Data yang diperoleh selama proses pembelajaran dan hasil tes evaluasi, dianalisis untuk membandingkan kelompok siswa dengan kepribadian mana yang lebih baik pada saat menggunakan aplikasi AR.

\section{Teknik Pengumpulan Data}

Teknik pengumpulan data yang digunakan dalam penelitian ini terdiri atas observasi (pengamatan), interview (wawancara), kuesioner (angket), catatan lapangan, dokumentasi.

\section{Teknik Analisis Data}

Teknik analisis data yang digunakan dalam penelitian ini diambil yaitu: data reduction, data display, dan conclusion drawing/verification.

\section{1) Data Reduction (Reduksi Data)}

Dalam penelitian ini reduksi data meliputi (1) data pengamatan dan data hasil wawancara terkait proses pembelajaran; (2) data hasil wawancara dan data angket terkait kendala-kendala yang dialami siswa pada saat menggunakan aplikasi mobile Augmented Reality (AR); (3) data angket terkait kepribadian siswa; (4) data hasil tes untuk mengukur penguasaan materi kubus dan balok pada siswa; (5) data hasil wawancara dengan siswa untuk mengetahui

lebih mendalam terkait penguasaan materi kubus dan balok.

2) Data Display (Penyajian Data)

Dalam penelitian ini penyajian data meliputi (1) data pengamatan dan data hasil wawancara terkait proses pembelajaran; (2) data hasil wawancara dan data angket terkait kendala-kendala yang dialami siswa pada saat menggunakan aplikasi mobile Augmented Reality (AR); (3) data angket terkait kepribadian siswa; (4) data hasil tes untuk mengukur penguasaan materi kubus dan balok pada siswa; (5) data hasil wawancara dengan siswa untuk mengetahui lebih mendalam terkait penguasaan materi kubus dan balok.

3) Conclusion Drawing/Verification

Kesimpulan dalam penelitian kualitatif adalah merupakan temuan baru yang sebelumnya belum pernah ada. Temuan dapat berupa deskripsi atau gambaran suatu obyek yang sebelumnya masih remangremang atau gelap sehingga setelah diteliti menjadi jelas, dapat berupa hubungan kasual atau interaktif, hipotesis atau teori.

Teknik Keabsahan Data

Teknik keabsahan data sangat perlu dilakukan agar data yang dihasilkan dapat dipercaya dan dipertanggungjawabkan kebenarannya secara ilmiah. Salah satu untuk mengetahui suatu keabsahan data yaitu dengan triangulasi. Triangulasi yang digunakan dalam penelitian ini yaitu triangulasi sumber, triangulasi waktu, triangulasi metode.

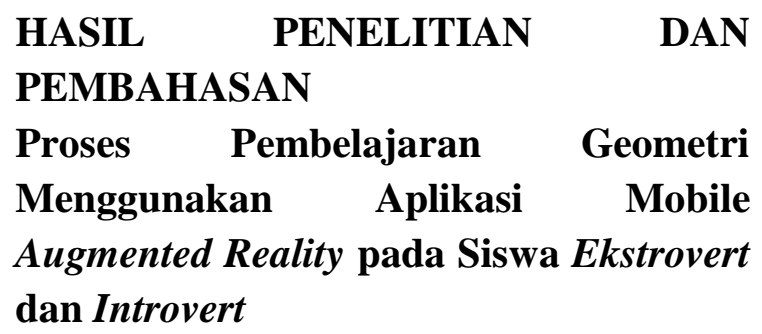

HASIL PENELITIAN DAN 
Sebelum dimulainya proses tipe kepribadian siswa berdasarkan hasil tes pembelajaran, peneliti sudah mengetahui angket kepribadian, yaitu sebagai berikut.

Tabel 1. Klasifikasi Tipe Kepribadian Siswa

\begin{tabular}{cll}
\hline No. & Siswa Berkepribadian Ekstrovert & Siswa Berkepribadian Introvert \\
\hline 1. & S1 & S9 \\
2. & S2 & $\mathrm{S} 10$ \\
3. & S3 & $\mathrm{S} 11$ \\
4. & S4 & $\mathrm{S} 12$ \\
5. & S5 & $\mathrm{S} 13$ \\
6. & S6 & $\mathrm{S} 14$ \\
7. & S7 & $\mathrm{S} 15$ \\
8. & S 8 & $\mathrm{~S} 16$ \\
9. & & $\mathrm{~S} 17$ \\
10. & & $\mathrm{~S} 18$ \\
11. & & $\mathrm{~S} 19$ \\
12. & & $\mathrm{~S} 20$ \\
\hline
\end{tabular}

Pada saat proses pembelajaran peneliti membagi siswa ke dalam kelompok sesuai dengan tipe kepribadiannya yaitu, kelompok siswa dengan tipe kepribadian ekstrovert dan kelompok siswa dengan tipe kepribadian introvert. Setelah siswa dibagi ke dalam kelompok, peneliti membagikan marker dari aplikasi yang berisi materi yang akan dipelajari yakni tentang kubus

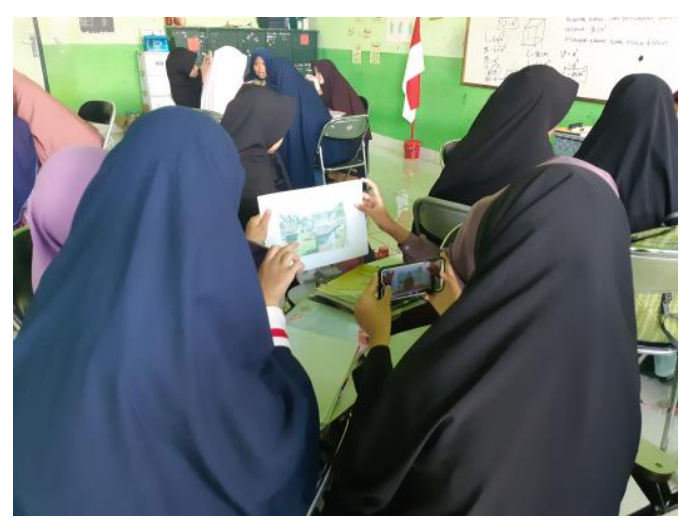

dan balok. Selanjutnya peneliti mengarahkan siswa untuk menggunakan aplikasi mobile augmented reality yang sudah diinstalkan di handphone masingmasing siswa. Melalui aplikasi mobile augmented reality siswa dapat mendengarkan penjelasan tentang unsurunsur kubus dan balok.

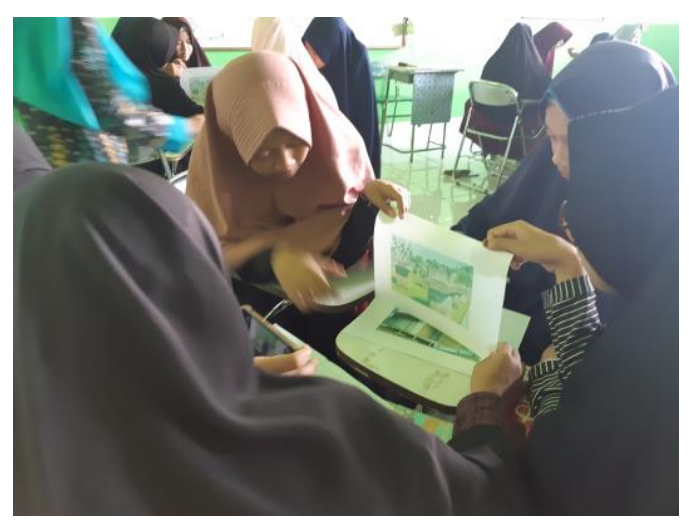

Gambar 1. Pembelajaran Pertemuan Pertama

Hasil temuan pada pertemuan pertama, memperlihatkan bahwa siswa masih bingung dan belum terbiasa menggunakan alat bantu aplikasi mobile augmented reality. Suasana kelas terlihat kurang kondusif karena masih ada beberapa siswa yang bertanya tentang penggunaan aplikasi mobile augmented reality. Akibat kondisi tersebut, banyak siswa yang masih kurang memahami materi sehingga guru perlu memberikan penjelasan kembali kepada siswa terkait materi unsur-unsur kubus dan 
balok. Setelah peneliti selesai menjelaskan materi, setiap kelompok diinstruksikan untuk menyelesaiakan masalah yang ada pada Lembar Kerja Siswa dengan cara diskusi. Kelompok siswa yang berkepribadian ekstrovert dapat melakukan diskusi dengan baik, dalam menyelesaikan setiap masalah dilakukan secara bersamasama, kelompok ekstrovert merupakan kelompok yang aktif karena mereka sering mengajukan pertanyaan ketika ada materi yang belum dipahami. Lain halnya dengan kelompok siswa yang berkepribadian introvert, mereka terlihat sibuk masingmasing. Ada yang menyelesaikan soal dan adapula yang masih memahami materi di aplikasinya. Sehingga, diskusi berjalan kurang baik. Kelompok introvert merupakan kelompok yang pasif karena mereka jarang mengajukan pertanyaan, peneliti harus memancing terlebih dahulu agar mereka dapat bertanya. Dari hasil diskusi setiap kelompok pada pertemuan pertama, diperoleh sebagai berikut:
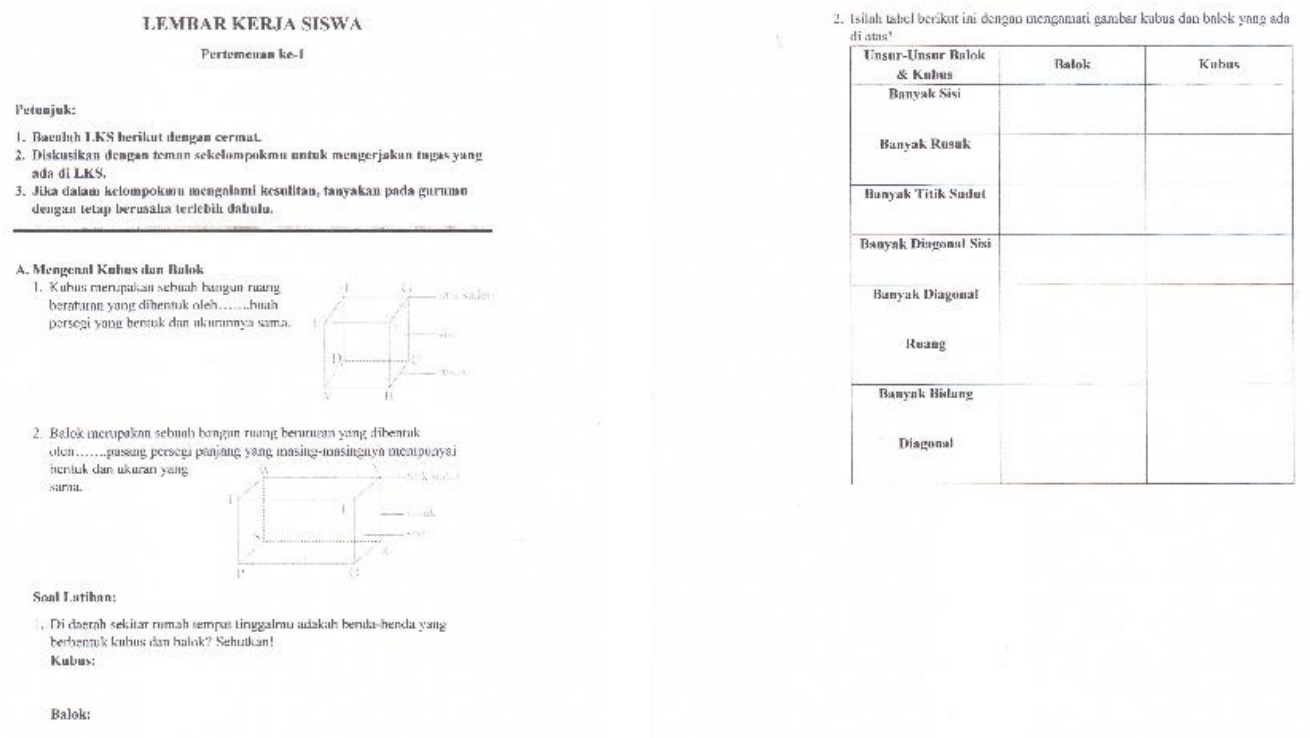

Gambar 2. Soal Lembar Kerja Siswa Pertemuan Pertama

Dari hasil diskusi menunjukkan bahwa kelompok ekstrovert mampu mendefinisikan kubus dan balok. Dapat memberikan contoh bentuk kubus dan balok yang ada di lingkungan sekitarnya. Serta mengetahui unsur-unsur yang ada pada kubus dan balok. Namun, tidak dapat menyebutkan titi-titik mana saja yang merupakan bagian dari unsur-unsur kubus dan balok. Hasil diskusi pada pertemuan pertama diperoleh bahwa kelompok ekstrovert memperoleh nilai hampir mendekati KKM. 


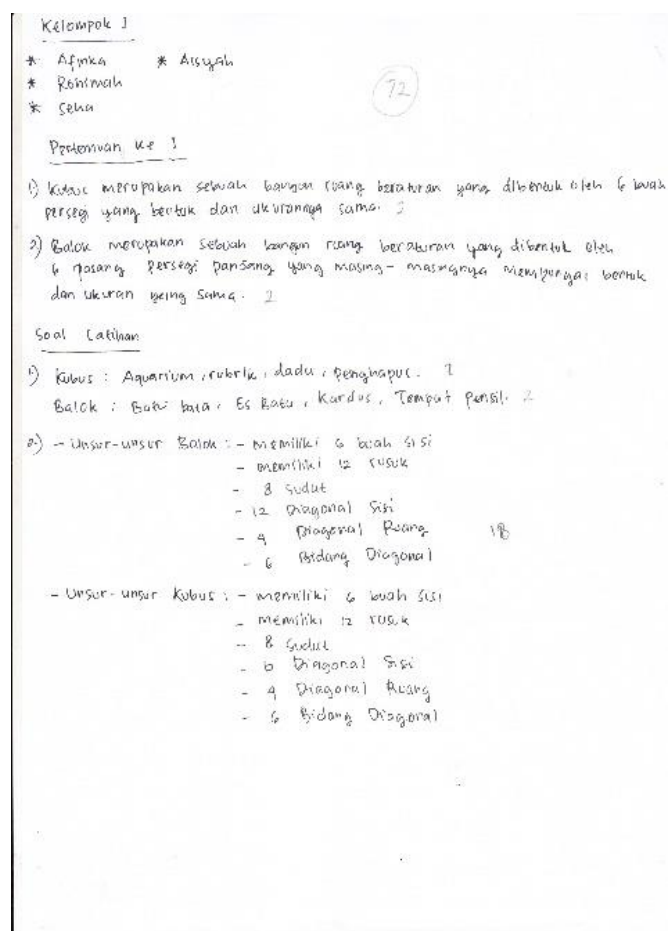

Gambar 3. Hasil Diskusi Kelompok Ekstrovert

Dari hasil diskusi menunjukkan bahwa kelompok introvert mampu mendefinisikan kubus dan balok. Dapat memberikan contoh bentuk kubus dan balok yang ada di lingkungan sekitarnya. Namun, kelompok introvert hanya mampu menyebutkan 3 (tiga) unsur-unsur kubus

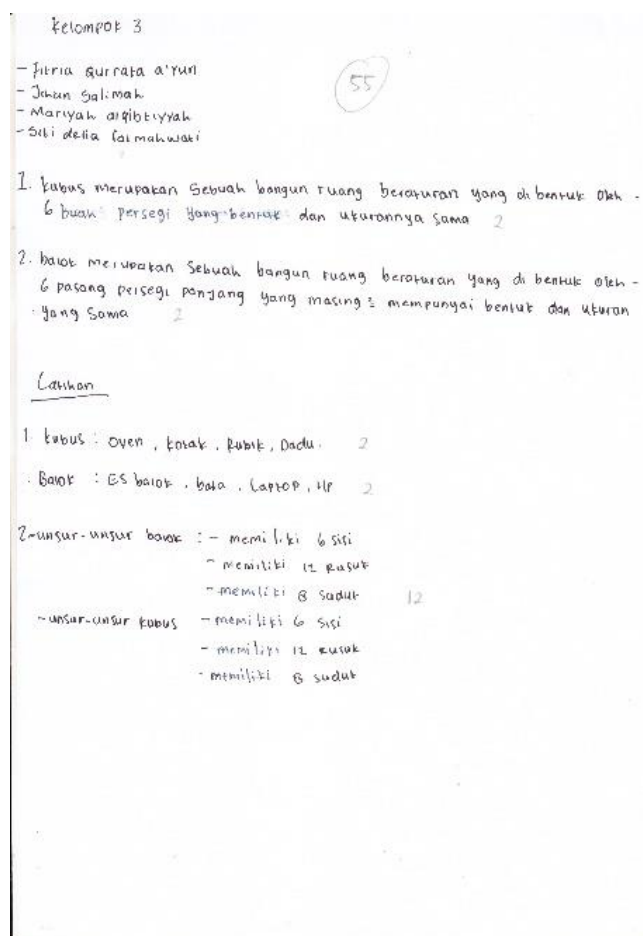

Gambar 4. Hasil Diskusi Kelompok Introvert

dan balok. Serta tidak disebutkan titik-titik mana saja yang merupakan bagian dari unsur-unsur kubus dan balok. Akibatnya, hasil diskusi pada pertemuan pertama kelompok introvert memperoleh nilai lebih di bawah KKM.
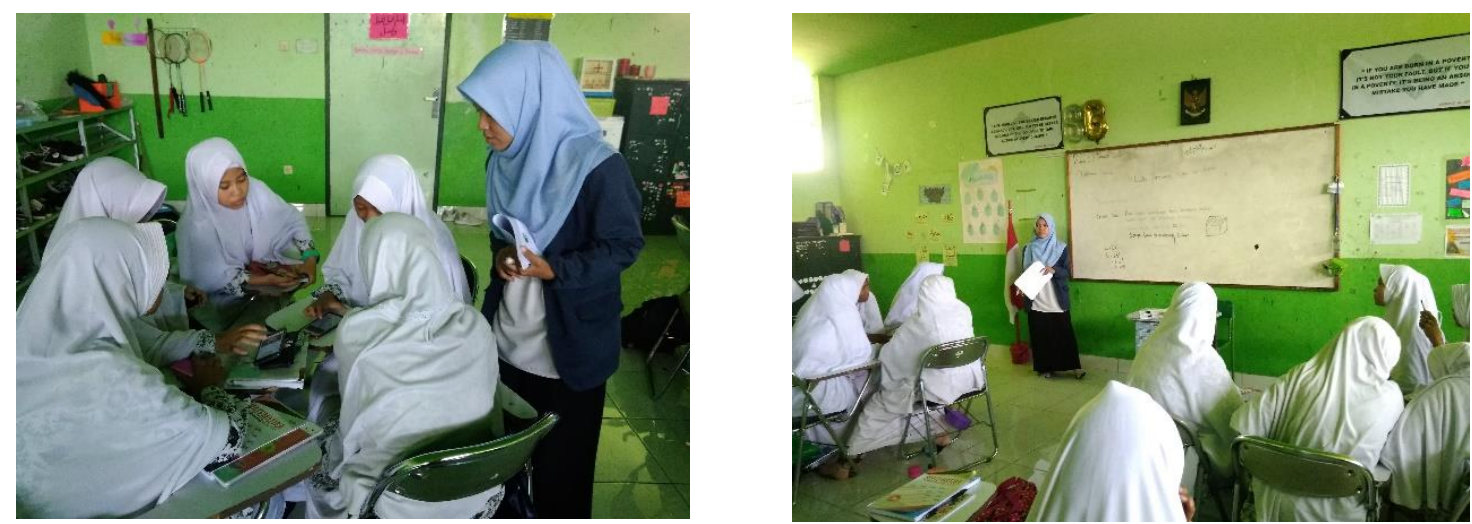

Gambar 5. Pembelajaran Pertemuan Kedua

Pada pertemuan kedua, peneliti memberikan instruksi kepada siswa untuk mempelajari materi tentang menentukan luas permukaan kubus dan balok melalui aplikasi mobile augmented reality. Siswa sudah mulai membiasakan diri dan tidak 
merasa bingung lagi saat menggunakan aplikasi mobile augmented reality pada pembelajaran. Suasana kelas terlihat kondusif jika dibandingkan dengan pertemuan sebelumnya. Walaupun siswa mempelajari materi lewat aplikasi namun peneliti sebagai fasilitator tetap memberikan contoh-contoh permasalahan yang berhubungan dengan luas permukaan kubus dan balok. Setelah peneliti selesai menjelaskan materi, setiap kelompok diberikan Lembar Kerja Siswa untuk diselesaikan dengan cara diskusi. Mereka melakukan diskusi dengan teman kelompok yang sama seperti pada pertemuan pertama. Kelompok ekstrovert seperti pada pertemuan sebelumnya, mereka selalu aktif ketika melakukan diskusi. Sering mengajukan pertanyaan jika ada materi yang belum dipahami. Sedangkan kelompok introvert masih pasif dalam melakukan diskusi, mereka tidak mengajukan pertanyaan jika peneliti tidak memancing mereka untuk bertanya. Dari hasil diskusi setiap kelompok pada pertemuan kedua, diperoleh sebagai berikut.

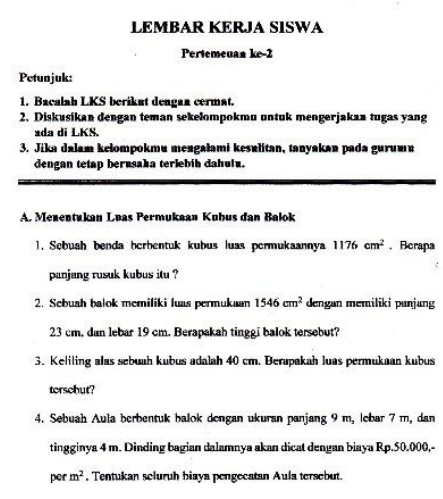

Gambar 6. Soal Lembar Kerja Siswa Pertemuan Kedua

\begin{abstract}
Dari hasil diskusi menunjukkan bahwa kelompok ekstrovert dapat menentukan panjang suatu rusuk kubus dengan diketahui luas permukaannya, dapat menentukan tinggi balok dengan diketahui luas permukaan balok, panjang balok, dan lebar balok. Selain itu dapat menentukan luas permukaan kubus dengan diketahui keliling alas kubus, dan dapat menentukan
\end{abstract}

biaya suatu pengecetan aula yang berbentuk balok dengan diketahui panjang, lebar, dan tinggi aula tersebut. Namun, di setiap penyelesaian tidak terdapat kesimpulan jawaban yang diperoleh. Pada pertemuan yang kedua nilai yang diperoleh kelompok ekstrovert lebih baik dari pertemuan sebelumnya. Dari yang nilainya 
masih di bawah KKM hingga sudah

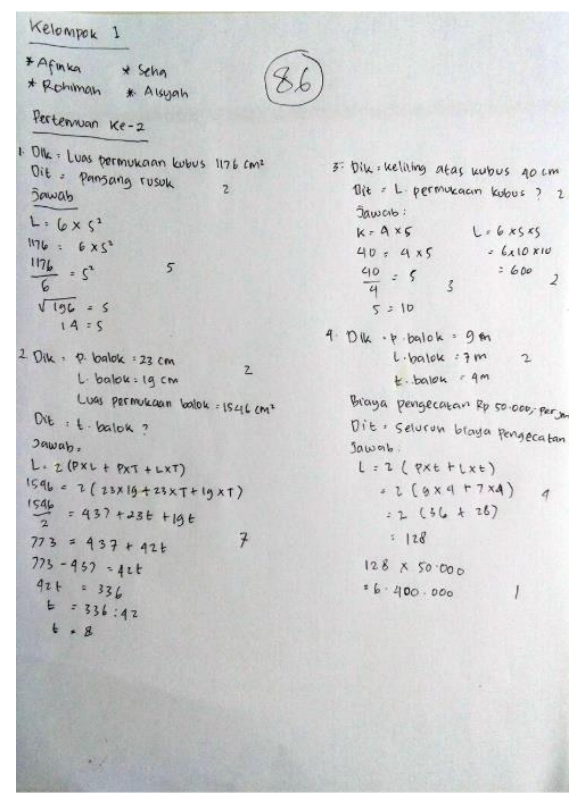

Gambar 7. Hasil Diskusi Kelompok Ekstrovert

Dari hasil diskusi menunjukkan bahwa kelompok introvert dapat menentukan panjang suatu rusuk kubus dengan diketahui luas permukaannya. Dalam menentukan tinggi suatu balok yang sudah diketahui panjang, lebar, dan luas permukaan suatu balok, terdapat salah konsep pada penyelesaian langkah ketiga. Selain itu dapat menentukan luas permukaan kubus dengan diketahui keliling

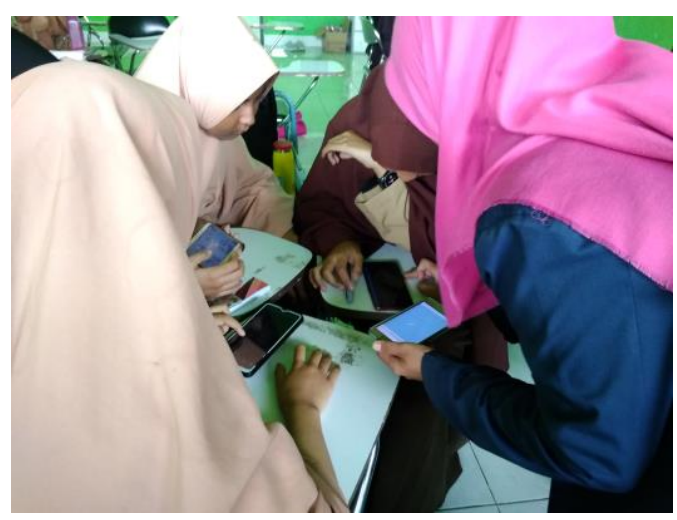

mencapai di atas KKM.

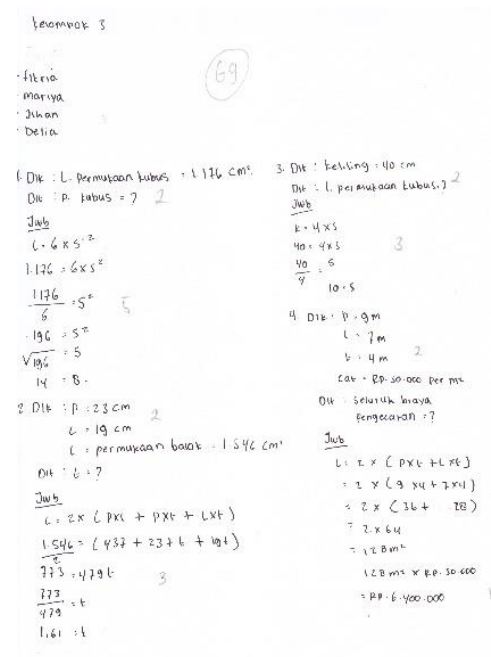

Gambar 8. Hasil Diskusi Kelompok Introvert

alas suatu kubus, juga dapat menentukan seluruh biaya pengecatan aula yang berbentuk balok dengan diketahui panjang, lebar, dan tinggi aula tersebut. Namun, di setiap penyelesaian tidak terdapat kesimpulan jawaban yang diperoleh. Pada pertemuan yang kedua nilai yang diperoleh kelompok introvert lebih baik dari pertemuan sebelumnya. Walaupun nilai yang diperoleh masih tetap dibawah KKM.

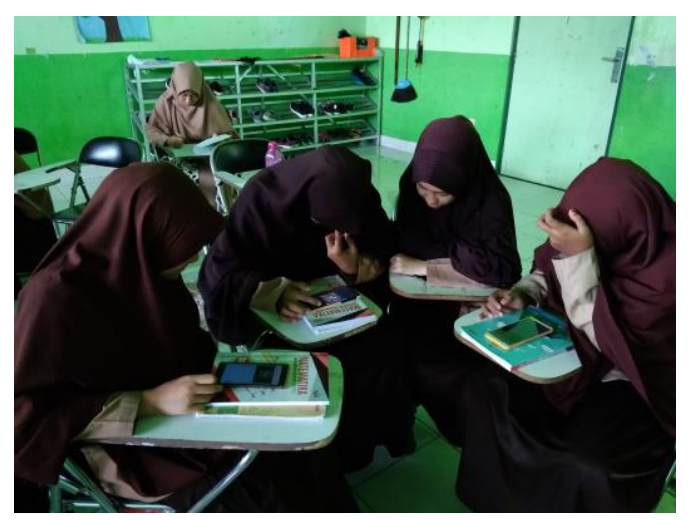

Gambar 9. Pembelajaran Pertemuan Ketiga

Pada pertemuan ketiga, peneliti memberikan instruksi kepada siswa untuk mempelajari materi tentang menentukan volume kubus dan balok melalui aplikasi 
mobile augmented reality. Siswa merasa senang menggunakan aplikasi pada pembelajaran. Suasana kelas pun semakin kondusif, karena siswa sudah tidak lagi merasa bingung menggunakan aplikasi tersebut. Peneliti merupakan fasilitator di dalam kelas, sehingga tetap memberikan penjelasan kembali kepada siswa. Setelah peneliti selesai menjelaskan materi, siswa diinstruksikan untuk menyelesaikan masalah yang ada pada Lembar Kerja Siswa dengan cara diskusi. Seperti pada pertemuan-pertemuan sebelumnya siswa melakukan diskusi dengan kelompoknya. Kelompok ekstrovert selalu menjadi kelompok yang paling aktif dalam pembelajaran, mereka lebih sering mengajukan pertanyaan jika dibandingnkan dengan kelompok introvert. Dalam menyelesaikan masalah, kelompok ekstrovert lebih senang bekerja sama. Lain halnya dengan kelompok introvert, mereka lebih senang menyelesaikan masalah masing-masing. Dari hasil diskusi setiap kelompok pada pertemuan ketiga, diperoleh sebagai berikut:

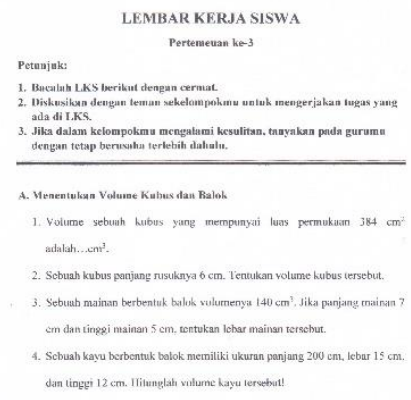

Gambar 10. Lembar Kerja Siswa Pertemuan Ketiga

Dari hasil diskusi menunjukkan bahwa kelompok ekstrovert dapat menentukan volume suatu kubus dengan diketahui luas permukaannya, serta dapat menentukan volume suatu kubus dengan diketahui panjang rusuknya. Dalam menentukan volume balok, kelompok introvert dapat menentukan lebar suatu balok dengan diketahui panjang balok, tinggi balok, dan volume balok, juga dapat menentukan volume kayu yang berbentuk balok dengan diketahui panjang, lebar, dan tinggi suatu balok tersebut. Seperti pada pertemuan kedua, dipertemuan ketiga pun tidak terdapat kesimpulan jawaban yang diperoleh, sehingga dapat mengurangi skor. Namun, nilai yang diperoleh oleh kelompok ekstrovert pada pertemuan ketiga lebih baik dari pertemuan sebelumnya. 


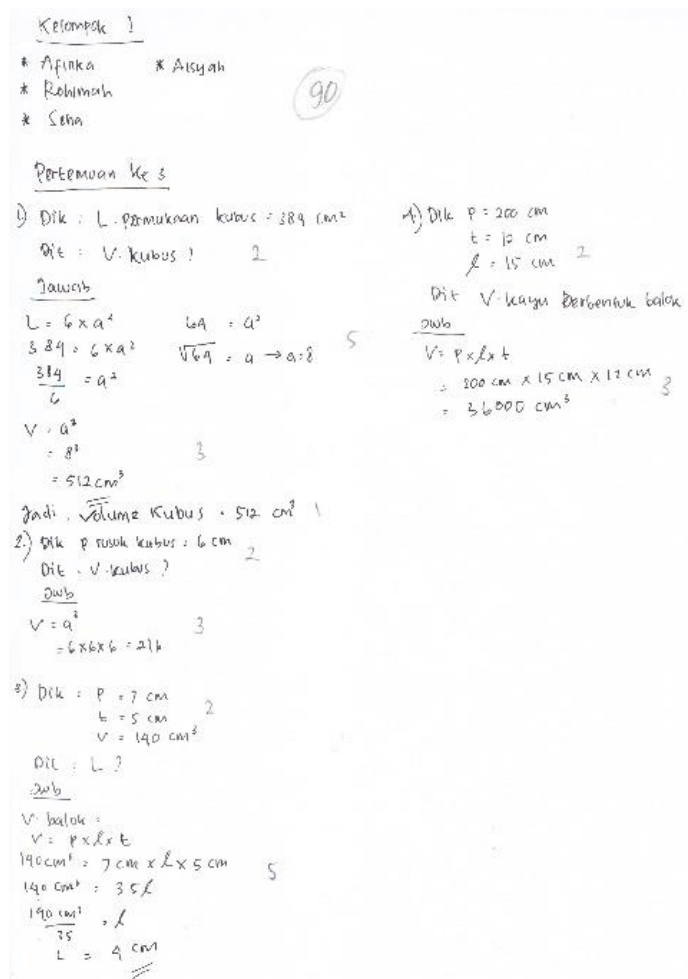

Gambar 11. Hasil Diskusi Kelompok Ekstrovert

Dari hasil diskusi menunjukkan bahwa kelompok introvert dapat menentukan volume suatu kubus dengan diketahui luas permukaannya, serta dapat menentukan volume kubus dengan diketahu panjang rusuk suatu kubus. Dalam menentukan volume balok, kelompok introvert dapat menentukan lebar suatu balok dengan diketahui panjang balok, tinggi balok, dan volume balok, tetapi tidak dapat menyelesaikan masalah menentukan volume kayu yang berbentuk balok dengan diketahui panjang, tinggi, dan lebar suatu balok tersebut. Seperti pada pertemuan

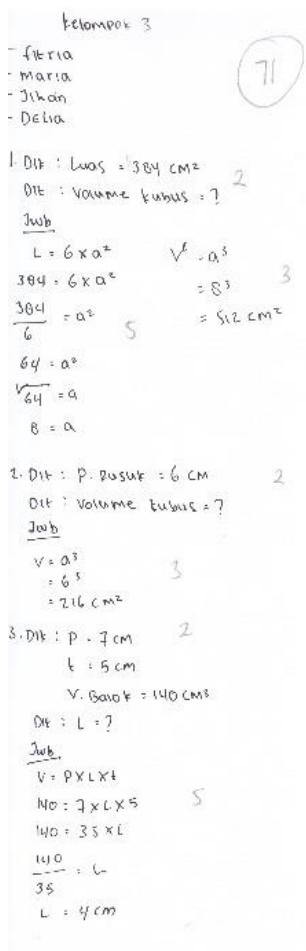

Gambar 12. Hasil Diskusi Kelompok Introvert

kedua, dipertemuan ketiga pun tidak terdapat kesimpulan jawaban yang diperoleh, sehingga dapat mengurangi skor. Nilai yang diperoleh oleh kelompok introvert pada pertemuan ketiga mengalami peningkatan namun masih tetap di bawah KKM.

Siswa melakukan diskusi dengan setiap kelompoknya yakni kelompok siswa yang berkepribadian ekstrovert dan introvert dari mulai pertemuan pertama sampai pertemuan ketiga untuk menyelesaiakan masalah yang ada pada Lembar Kerja Siswa dan diperoleh hasil sebagai berikut:

Tabel 2. Hasil Diskusi

\begin{tabular}{|c|c|c|c|c|c|}
\hline \multirow[t]{2}{*}{ Kelompok } & \multicolumn{3}{|c|}{$\begin{array}{l}\text { Nilai Tiap } \\
\text { Pertemuan }\end{array}$} & \multirow[t]{2}{*}{ Jumlah } & \multirow{2}{*}{$\begin{array}{l}\text { Rata- } \\
\text { rata }\end{array}$} \\
\hline & 1 & 2 & 3 & & \\
\hline Ekstrovert & 72 & 86 & 90 & 248 & 82,67 \\
\hline Introvert & 55 & 69 & 71 & 195 & 65 \\
\hline
\end{tabular}


Hasil di atas menunjukan bahwa, pada pertemuan pertama dalam menyelesaikan masalah tentang unsurunsur kubus dan balok. Kelompok ekstrovert memperoleh nilai 72 dan kelompok introvert memperoleh nilai 55 . Pada pertemuan kedua dalam menentukan luas permukaan kubus dan balok. Kelompok ekstrovert memperoleh nilai 86 dan kelompok introvert memperoleh nilai 69. Pada pertemuan ketiga dalam menentuukan volume kubus dan balok. Kelompok ekstrovert memperoleh nilai 90 dan kelompok introvert memperoleh nilai 71. Sehingga dari pertemuan pertama sampai ketiga diperoleh rata-rata nilai dari kelompok ekstrovert yaitu 82,67 dan kelompok introvert yaitu 65. Hal ini menunjukkan bahwa dalam pembelajaran yang dilakukan secara berkelompok, kelompok ekrovert memperoleh nilai lebih baik dari pada kelompok introvert.

\section{Penguasaan Materi Kubus dan Balok Pada Siswa Ekstrovert dan Introvert \\ Daya tangkap siswa dalam} memahami suatu materi berbeda-beda terutama pada siswa ekstrovert dan introvert. Sehingga dalam menguasai materi pun berbeda seperti pada materi kubus dan balok. Untuk mengetahui penguasaan materi kubus dan balok pada siswa ekstrovert dan introvert secara individu sebelum pembelajaran peneliti melakukan pre tes terlebih dahulu. Setelah itu siswa mempelajari materi kubus dan balok menggunakan aplikasi mobile augmented reality. Setiap pertemuan siswa melakukan diskusi dengan kelompoknya untuk menyelesaikan masalah tentang materi yang terkait. Setelah pembelajaran selesai peneliti melakukan post tes secara individu untuk mengetahui penguasaan materi kubus dan balok pada siswa ekstrovert dan introvert, dan diperoleh hasil sebagai berikut:

Tabel 3. Hasil Skor Siswa Ekstrovert dan Introvert

\begin{tabular}{c|cccc}
\hline \multirow{2}{*}{$\begin{array}{c}\text { Siswa } \\
\text { Berkepribadian }\end{array}$} & \multicolumn{3}{|c}{ Pre Tes } & Post Tes \\
\cline { 2 - 5 } & Jumlah & Rata-rata & Jumlah & Rata-rata \\
\hline Ekstrovert & 128 & 16 & 229 & 28,63 \\
Introvert & 189 & 15,83 & 366 & 30,5 \\
\hline
\end{tabular}

Berdasarkan hasil di atas, diperoleh bahwa rata-rata skor pre tes siswa yang memiliki tipe kepribadian ekstrovert yaitu 16 dan siswa yang memiliki tipe kepribadian introvert yaitu 15,83. Dari hasil skor pre tes tersebut menunjukkan bahwa siswa yang memiliki kepribadian ekstrovert memperoleh rata-rata hampir sama dengan siswa yang memiliki kepribadian introvert. Setelah dilakukan pre tes peneliti memberikan materi kubus dan balok kepada siswa dengan menggunakan aplikasi mobile augmented reality. Kemudian peneliti melakukan post tes secara individu untuk mengetahui penguasaan materi kubus dan balok pada siswa ekstrovert dan introvert. Rata-rata skor siswa yang memiliki tipe kepribadian ekstrovert yaitu 28,63 dan siswa yang memiliki tipe kepribadian introvert yaitu 
30,5. Hasil tersebut menunjukkan bahwa jika dilakukan tes secara individu, siswa introvert memperoleh nilai lebih tinggi dari siswa ekstrovert.

\section{Pembahasan}

Berdasarkan temuan yang diperoleh pada pembelajaran yang dilakukan secara berkelompok dari pertemuan pertama sampai pertemuan ketiga. Kelompok siswa yang berkepribadian ekstrovert termasuk kelompok yang aktif, sering mengajukan pertanyaan kepada peneliti baik perihal materi yang belum dipahami ataupun di luar materi karena ekstrovert memiliki karakteristik berani dalam menyampaikan apa yang ada dipikirannya. Hal ini sejalan dengan pendapat Alwilsol (2004) bahwa ekstrovert memiliki sifat banyak bicara dan aktif. Selain itu kelompok ekstrovert selalu kerja sama dalam menyelesaikan masalah karena bagi ekstrovert denggan kerja sama dapat mempermudah mereka dalam menyelesaikan masalah. Hal ini sejalan dengan pendapat menurut Habibi (2016) bahwa siswa yang berkepribadian ekstrovert lebih suka belajar secara berkelompok. Tentunya bagi siswa ekstrovert sangat menguntungkan jika pembelajaran dilakukan dengan berkelompok. Sedangkan, kelompok siswa yang berkepribadian introvert terlihat masing-masing dalam menyelesaikan masalah. Karena bagi introvert menyelesaikan masalah dengan cara sendiri akan membuat mereka lebih fokus dan teliti. Hal ini sejalan dengan pendapat Rahayu dan Fauziah (2017) kepribadian introvert adalah individu yang mempunyai ciri-ciri suka belajar sendiri. Sehingga, siswa introvert tidak menyukai pembelajaran yang dilakukan secara berkelompok. Selain itu, kelompok introvert termasuk kelompok yang kurang aktif dalam pembelajaran, dan jarang bertanya. Karena introvert memiliki karakteristik pemalu sehingga enggan dalam bertanya maupun berpendapat. Hal ini sependapat apa yang disampaikan oleh Jung (1921) tipe kepribadian introvert adalah individu yang cenderung pemalu. Akibatnya apabil ada materi yang belum dipahami mereka lebih sering bertanya kepada teman yang mereka percaya. Berdasarkan hasil diskusi setiap kelompok dalam menyelesaikan masalah yang ada pada Lembar Kerja Siswa, kelompok ekstrovert memperoleh rata-rata nilai lebih tinggi dibandingkan dengan kelompok introvert.

Namun, temuan yang diperoleh oleh peneliti dalam melakukan pre tes dan post tes kepada setiap individu berdasarkan tipe kepribadian. Siswa yang berkepribadian introvert memperoleh rata-rata nilai lebih tinggi dari siswa yang berkepribadian ekstrovert. Menurut Rosida dan Astuti (2015) kepribadian introvert memiliki ciriciri teliti dan sungguh-sungguh dalam pekerjaan. Sehingga, dalam menyelesaikan masalah siswa introvert melakukannya dengan teliti dan belajar dengan giat. Hal ini dapat mempengaruhi hasil tes siswa introvert. Sedangkan menurut Rahayu dan Fauziah (2017) kepribadian ekstrovert adalah individu yang mempunyai ciri-ciri tidak suka belajar sendiri. Sehingga, jika dilakukan tes secara individu menjadi suatu kelemahan bagi siswa ekstrovert dan mengakibatkan rata-rata nilai nilai siswa ekstrovert rendah. Lain halnya yang disampaikan oleh Chinelo, Francisca dan Blessing (2016) bahwa dalam pengajaran matematika baik siswa ekstrovert maupun introvert memperoleh peningkatan yang baik selama pembelajaran. 


\section{SIMPULAN DAN SARAN}

\section{Simpulan}

Dalam proses pembelajaran siswa ekstrovert lebih aktif dari siswa introvert. Siswa ekstrovert lebih menyukai belajar secara berkelompok sehingga hasil diskusi yang diperolehpun lebih tinggi. Namun, hasil yang tes yang dilakukan secara individu justru siswa introvert yang lebih unggul hal ini karena siswa introvert lebih teliti dalam menyelesaikan soal tes.

\section{Saran}

Berdasarkan hasil penelitian dan kesimpulan, maka peneliti ingin mengajukan saran bagi peneliti selanjutnya. Bahwa dapat ditindaklanjuti hasil penelitian ini dengan jumlah subjek yang sama ataupun berbeda. Selain itu, untuk memperoleh hasil penelitian yang maksimal diperlukan alokasi waktu yang lebih lama serta dilakukan pada pokok bahasan yang berbeda den jenjang pendidikan yang berbeda pula dengan subjek yang lebih luas.

\section{DAFTAR PUSTAKA}

Abdul, R. dkk. (2010) 'The Effects of GeoGebra on Mathematics Achievement: Enlightening The Effects of GeoGebra on Mathematics Achievement: Enlightening Coordinate Geometry Learning', (February 2015). doi: 10.1016/j.sbspro.2010.12.095.

Alwilsol. 2004 Psikologi Kepribadian. Malang: UMM Press.

Ariani, A., \& Widjajanti, D. B. (2016). Pengembangan

Perangkat

Pembelajaran Geometri SMP dengan Pendekatan Open-Ended Berorientasi Kemampuan Berpikir Kritis. PYTHAGORAS: Jurnal Pendidikan Matematika, 8(1), 21-32. https://doi.org/10.21831/pg.v8i1.8491

Arini, Z. (2016) 'Profil Kemampuan
Penalaran Siswa Smp Dalam Menyelesaikan Masalah Matematika Ditinjau Dari Tipe Kepribadian Extrovert Dan Introvert', MATHEdunesa, 5(2).

Astriawati, N., Wibowo, W. dan Widyanto, H. 2020. 'Designing Android-Based Augmented Reality Application on Three Dimension Space Geometry', in Journal of Physics: Conference Series. doi: 10.1088/17426596/1477/2/022006.

Bajura, M. dan Neumann, U. (1995) 'Dynamic registration correction in augmented-reality systems', Proceedings - Virtual Reality Annual International Symposium, (September), pp. 189-196. doi: 10.1109/vrais.1995.512495.

Banu, S. M. (2012) 'Augmented Reality System Based on Sketches for Geometry Education', 2012 International Conference on ELearning and E-Technologies in Education, ICEEE 2012, pp. 166-170. doi: 10.1109/ICeLeTE.2012.6333384.

Bergig, O. dkk. (2009) 'In-place 3D Sketching for Authoring and Augmenting Mechanical Systems', Science and Technology Proceedings IEEE 2009 International Symposium on Mixed and Augmented Reality, ISMAR 2009, pp. 87-94. doi: 10.1109/ISMAR.2009.5336490.

Budiarto, M. T., \& Artiono, R. (2019). Geometri dan Permasalahan dalam Pembelajarannya (Suatu Penelitian Meta Analisis). JUMADIKA: Jurnal Magister Pendidikan Matematika, 1(1), 9-18. https://doi.org/10.30598/jumadikavol1 iss1year2019page9-18

Chiang, T. H. C., Yang, S. J. H., \& Hwang, G. J. (2014). An Augmented RealityBased Mobile Learning System to Improve Students' Learning Achievements and Motivations in Natural Science Inquiry Activities. Educational Technology and Society, 
17(4), 352-365.

Chinelo, O. E., Francisca, O. N., \& Blessing, M. A. (2016). Enhancing Mathematics Achievement of Introverted and Extroverted Secondary School Students through the use of Advance Organizers. Journal of Educational Research and Reviews, 4(3), 27-32.

Edwin Dwi Putranto. (2018). Kemendikbud: Hanya 40 Persen Guru Siap dengan Teknologi. Dalam Republika, 4 Desember 2018. Bandung. Tersedia di https://www.republika.co.id/berita/p endidikan/eduaction/18/12/03/pj60e j335-kemendikbud-hanya-40persen-guru-siap-dengan-teknologi (Diunduh 25 Oktober 2019)

Fatmawati, I., \& Khabibah, S. (2019). Profil Siswa SMP Dalam Memecahkan Masalah Matematika Ditinjau dari Tipe Kepribadian. Jurnal Ilmiah Pendidikan Matematika, 8(2), 328-337.

Habibi, A. (2016). Perbedaan Hasil Belajar Matematika Siswa SMP yang Berkepribadian Ekstrovert dan Introvert pada Pokok Bahasan Sistem Persamaan Linier. Educazione, 4(1), 61-71.

Hamiti, M. dan Reka, B. (2012) 'Teaching with Technology', Procedia - Social and Behavioral Sciences, 46, pp. 1171-1176. doi: 10.1016/j.sbspro.2012.05.269.

Hung, Y. H., Chen, C. H. dan Huang, S. W. (2017) 'Applying Augmented Reality to Enhance Learning: A Study of Different Teaching Materials', Journal of Computer Assisted Learning, 33(3), pp. 252-266. doi: 10.1111/jcal.12173.

Jung, C. G. 1921. Psychological Types. Online. Tersedia di www.Abika.com (diunduh 19 Oktober 2019)

Liao, Y. T., Yu, C. H. dan Wu, C. C. (2015) 'Learning Geometry with Augmented Reality to Enhance Spatial Ability', Proceedings - 2015
International Conference on Learning and Teaching in Computing and Engineering, LaTiCE 2015, pp. 221222. doi: 10.1109/LaTiCE.2015.40.

Manurung, R. T. dkk. (2018) 'Multimedia Flash Basic Mathematic Learning for Primary School', International Journal of Engineering and Technology(UAE), 7(2.13 Special Issue 13), pp. 464-466. doi: 10.14419/ijet.v7i2.13.18142.

Nuriyatin, S., \& Hartono, H. (2016). Pengembangan Pembelajaran Penemuan Terbimbing Untuk Meningkatkan Berpikir Kritis dan Motivasi Belajar Geometri di SMP. PYTHAGORAS: Jurnal Pendidikan Matematika, $\quad 11(2), \quad 207$. https://doi.org/10.21831/pg.v11i2.106 56

Rahayu, Y. M., \& Fauziah, A. N. M. (2017). Kemampuan Penalaran Siswa SMP Dalam Menyelesaikan Masalah Ditinjau dari Kepribadian Introvert dan Ekstrovert pada Materi Kalor. EJournal Unesa, 05(02), 138-146.

Rahmawati, F. (2011). Pengaruh Pembelajaran Geometri dengan Pendekatan Induktif. 01, 73-79.

Rosida, \& Astuti. (2015). Perbedaan Penerimaan Teman Sebaya Ditinjau Dari Tipe Kepribadian Ekstrovert Dan Introvert. Empati: Jurnal Karya Ilmiah S1 Undip, 4(1), 77-81.

Sudirman, S. dkk. (2020) 'Integrating ethnomathematics into augmented reality technology: Exploration, design, and implementation in geometry learning', Journal of Physics: Conference Series, 1521(3). doi: 10.1088/17426596/1521/3/032006.

Sudirman, S., Yaniawati, R. P., Melawaty, M., \& Indrawan, R. (2020). Integrating Ethnomathematics into Augmented Reality Technology: Exploration, Design, and Implementation in Geometry Learning. Journal of Physics: Conference Series, 1521(3). 
https://doi.org/10.1088/1742-

6596/1521/3/032006

Suwito, A. (2017). Analisis Berpikir Secara

Geometri dalam Menyelesaikan

Masalah Aljabar Pada Kelas VIII.

Prosiding Seminar Nasional

Etnomatnesia, 64-69.

Zainul, R., \& Prima, C. B. (2018). Desain

Geometri Sel PV.

https://doi.org/10.31227/osf.io/7n8t4. 
